\title{
ERRATUM
}

\section{Ecology of macrozoobenthic communities in two plateau lakes of Southwest China}

\author{
CUI Yongde (崔永德), WANG Hongzhu (王洪铸) \\ (C) Springer-Verlag 2009

\section{Erratum to: Chinese Journal of Oceanology and Limnology} \\ DOI: 10.1007/s00343-008-0345-4
}

The original version of this article contains a mistake in font setting on p.350. The last part of Table 3 note, i.e. "biomass...molluscs (Liang et al., 1995)" should belong to the paper body. Therefore, the last sentence in the right-hand column above Table 3 should read "In the lakes, the density and biomass varied in different ways, greater biomass of Yangzong Lake was observed in summer and winter, because of the occurrence of Bellamya sp. Due to the fact that oligochaetes comprised $95.0 \%-99.4 \%$ in total density of the lakes, the seasonal change of benthic density was governed by oligochaetes, while those of Changjiang shallow lakes were governed by molluscs (Liang et al., 1995)." The editors apologize to the authors. 